\title{
Municipal Energy Management Model for Cuban First Level Municipalities
}

\author{
Jenny Correa Soto ${ }^{1}$, Juan J. Cabello Eras ${ }^{1,2}$, Dianelys Nogueira Rivera ${ }^{3}$, Dries Haeseldonckx ${ }^{4}$, Alexis \\ Sagastume Gutierrez ${ }^{2}$ and Luis Felipe Silva de Oliveira $^{2}$ \\ ${ }^{1}$ University of Cienfuegos, Road to Rodas, $\mathrm{km} \mathrm{4,} \mathrm{Cuatro} \mathrm{Caminos,} \mathrm{Cienfuegos,} \mathrm{Cuba}$ \\ ${ }^{2}$ Universidad de la Costa, Street 58 \# 55e66, Barranquilla, Atlántico, Colombia. \\ ${ }^{3}$ University of Matanzas, Road to Varadero, Matanzas, Cuba. \\ ${ }^{4} \mathrm{KU}$ Leuven, Campus Group T Leuven, Belgium.
}

Received 15 September 2018; Accepted 29 December 2018

\begin{abstract}
The Government of Cuba proposed in the year 2011 an update of the economic and social model, where the management of energy is an element of influence in the economy of the country. This led to the approval of a policy for the development of renewable sources and the efficient use of energy. Another important aspect is the National Plan for development until 2030, which considers the use of natural resources including energy, environmental impacts, and its link with the local development. However, in the municipalities, there are few studies on local energy management (LEM), and they lack the essential elements to guarantee it. This study defined the elements of LEM for the management models of local governance in Cuba, the energy context, and the scenario for the development of LEM in the country. The results suggest a model for LEM that integrates its elements to the functions of local government in energy decisions that influence the economy, society, the environment and local development.
\end{abstract}

Keywords: developing countries, environment, governance, local development, local energy management

\section{Introduction}

The worry about climate change, resource depletion, and guarantee of clean energy supply and its efficient use have been increased since the ending of last century $[1,2]$. One of the mains challenges of the humanity is changing the current fossil fuel based energy model for a new model based in the massive use of cleaner and renewable energy source, in addition, a significant improvement of the efficiency in the energy source use has to be reached. One of the ways, in order to do it, is the gradual change from a centralized energy supply founded to large-scale decentralized energy production and management approach [4].

The trend of growing the people living in cities look irreversible and expectations are $66 \%$ of the total population will live in cities in 2050[4]. The energy consumed in cities is predicted to rise from $60 \%$ to $73 \%$ of worldwide energy demand between 2006 and 2030 [5]. The moderns cities have to improve current energy systems and find new solutions coordinating factors as the intermittency of renewable sources, the increasing of energy demand and increasing demand of transport systems with more energy efficiency, among other things [6].

The importance of energy management to contribute to urban centers sustainability is highlighted by Calvillo et al. [7]. Local energy management (LEM) and defined as the strategic planning of the local energy needs and its use in the short, medium and long-term implemented at regional, municipal, and neighborhood scales. LEM application in

*E-mail address: jcabello2@cuc.edu.co

ISSN: 1791-2377 @ 2018 Eastern Macedonia and Thrace Institute of Technology. All rights reserved. doi:10.25103/jestr.116.01 several countries and municipalities have improved the energy's local systems becoming more efficient, economic and amiable to the environment [8]

First experiences in LEM were in the late 80s in Sweden, where an energy model was developed for energy planning in municipalities [9] and since then many initiatives, which have contributed to improving the performance of local governments in maintaining their finances and reducing impacts on the environment of the town have been developed mainly in developed countries. [10].

Despite the Economic Commission for Latin America and the Caribbean [11] recognizes the needs of improving the energy efficiency in local level, to the best knowledge of the authors, there are no studies in the specialized literature addressing LEM experiences in Latin-American countries.

Also, there is in Cuba a trend of population growth in urban areas [12]. Nevertheless, the energy supply is an issue of the national authorities and municipal authorities have a limited role to forecast energy demand and work in saving programs in order to satisfy the citizen's requirements with energy amount assigned by the central government $[13,14,15]$.

In the neoliberal worldwide predominant scenario, LEM have been focused mainly on a techno-economic model involving the rapid deployment of renewable energy technologies as wind, biomass, hydro and solar power. However successful deployment of urban energy initiatives is not only a techno-economic optimization problem, also is a process in which the 'social' and the 'technical' are closely linked, and technologies evolve together with government programs [16].

The Cuban socioeconomic system is far from neoliberalism and has some several particularities which 
motivate it to study. Is human-centered and development is understood as the expansion of the human potentialities, social Cuban policies during the last 60years have human opportunities at the center and equity as an essential part of the development and social justice. The culture of savings and the rational use of resources is also of core importance for the Cuban model imposed by the US embargo [17], also policies that acknowledge saving opportunities as one of the main resources for the country [18]. In addition in Cuba almost all products or services companies are government own which would facilitate the role of local government in order to improve the energy efficiency

Despite local's governments in Cuba manage directly education, health and sport practices services, water supply and treatment, local and short-range transportation and locals industries, its share of national energy consumption is significant account $51 \%$ of diesel fuel and $30 \%$ of electricity [19], currently there are a lack of tools and competencies for energy management and an institutional mechanism to do it $[12,13,15]$.

The paper is focused on the study of the interrelations between the main stakeholders of the energy chain in first level Cuban municipalities and the design of energy management model to provide local governments with a procedure and tools for LEM according to the current conditions in Cuba.

\section{Literature review}

Three stakeholders integrate the LEM framework: 1 - the users which provide information about the current and forecasted energy demand and its satisfaction, 2 - the authorities which should drive technical assistance, implementation and monitoring local and regional energy policies and compliance and promoting institutional change in local governments and public administration; 3 commercial actors that are responsible for facilitating the exchange of experiences, the creation and sharing of innovative ideas. The main benefits of LEM are the reduction of the cost of municipal energy, the emissions of greenhouse gasses and a reduction of dependence from the use of traditional electrical systems and dependence on energy imports [20,21].

The capacity of local authorities to develop and managing energy models to improve its energy sustainability throughout the use of renewable energy sources (RES), energy efficiency strategies and the good balance of local energy import-export, the use of online tools, local development planning, innovative ideas and socialization [22,23]. Table 1 shows successful examples of municipal energy management implementation

Table 1 Energy municipal management implementation

\begin{tabular}{|c|c|c|c|}
\hline Year & Country & Municipality/ City & Energy municipal management case \\
\hline 1997 & Germany & Würzburg Heidingsfeld City & A Model for Regional and Municipal Energy Optimization (DEECO) [24] \\
\hline 1998 & Italy & Palermo & Tools for Municipal Energy Planning[25] \\
\hline 1999 & Austria & Carinthia & Indicators for the Integration of Alternative Energy Sources[26] \\
\hline 1999 & Sweden & Linköping City & Optimization Model of Power System (MODEST) [27] \\
\hline 2004 & Sweden & Ciudad de Linköping & Model Mixed Integer Linear Programming for Energy System Analysis[28] \\
\hline 2004 & $\begin{array}{l}\text { England and } \\
\text { Wales }\end{array}$ & twenty-two cities & $\begin{array}{l}\text { Experience in Managing Emissions of Greenhouse Gasses from Local Energy } \\
\text { Management [29] }\end{array}$ \\
\hline 2005 & Spain & $\begin{array}{l}\text { Five municipalities in the } \\
\text { province of Jaén }\end{array}$ & Municipal Plans Optimization (POES) [30] \\
\hline 2007 & Sweden & Lucknow City & Energy Management Model[31] \\
\hline 2009 & Sweden & $\begin{array}{l}\text { Thirteen municipalities in the } \\
\text { province of Östergötland }\end{array}$ & Method for Municipal Energy Planning[32] \\
\hline 2009 & Canada & Ten town & Local Energy Management Model[33] \\
\hline 2010 & Spain & $\begin{array}{l}\text { City of Madrid, Rivas- } \\
\text { Vaciamadrid }\end{array}$ & Local Strategy [34] \\
\hline 2010 & Canada & Toronto-Niagara, Waterloo & Model for the Development of a Municipal Energy Planning[35] \\
\hline & China & Hohhot & \\
\hline 2010 & $\begin{array}{l}\text { Portugal } \\
\text { USA }\end{array}$ & $\begin{array}{l}\text { fourteen municipalities } \\
\text { Boston }\end{array}$ & $\begin{array}{l}\text { Methodology for Developing Energy Sustainability Indicators for Local Energy } \\
\text { Planning[3] }\end{array}$ \\
\hline 2011 & Denmark & Applied in all municipalities & Municipal Energy Planning Strategy[36] \\
\hline 2011 & China & Beijing & Method for a Municipal Energy Planning System[37] \\
\hline 2012 & Italia & Twelve municipalities & $\begin{array}{l}\text { Methodology for Municipal Energy Planning } \\
\text { Regional Master Plan (REMP) [38] }\end{array}$ \\
\hline 2015 & China & Shanghai & Method and Tolls for Community Energy Planning[39] \\
\hline 2016 & Sweden & Five municipalities & A Proposal of Factors that Influence in Municipal Climate and Energy Planning[40] \\
\hline
\end{tabular}

There are several key factors to successful LEM: 1. energy planning at the municipal level based in close relations between the community and politic, institutional and technical dimensions $[9,32,41,42] ; 2$. The planning on strategic level in order to forecast local energy demand in the short, middle and long-terms [7] and 3. planning the 
development of local energy resources, the energy importexport balance, the storage, the conversion and transmission systems applications, taking account the environmental issues. [42]

The factors influencing LEM were divided into two kinds by Fenton et al. [40]. Contextual factors are the municipality size, population, amount of companies and bureaucracy structures and non-contextual factors are the decision making process, management tools used by local policymakers, levels of interaction and exchange between stakeholders and other internal or external actions that affect the scope, objectives and LEM performance.

\section{Cuba energy scenario}

There are in Cuba fifteen provinces and one hundred sixtyeight municipalities of which thirteen cities are classified as the first level according to population [43]. Also, there is in this city a significant energy consumption and energy mangement lack [13]. In Cuba the energy savings are strategic and understand inside of the national security framework because there is a very strong dependence from oil importations [45], first from the Soviet Union in the past and more recently from Venezuela, which makes Cuba vulnerable to political changes abroad and to market variations of the oil prices . Cyclic crisis have resulted from this dependence over the years. In 1989, the disintegration of the Soviet Union caused a shortage of Cuban fuel imports, provoking the biggest energy crisis thus far [46]. Currently, Cuba is facing a new crisis caused by a reduction of the fuel imports from Venezuela [47]. Therefore, the energy security is a key factor in the economic development of the country [48]. Cuban energy sector has been improving gradually, 97 $\%$ of the country is electrified, from 2006 a national program for a distributed generation have developed covering more than $40 \%$ of electricity [49]. The enegy program to 2030
Cuban energy sector has been improving gradually, $97 \%$ of the country is electrified, from 2006 a national program for a distributed generation have developed covering more than $40 \%$ of electricity [49]. The energy program in 2030 have as the main goal reach $24 \%$ or electricity from renewable [50] and energy efficiency strategies throughout social and economic structures are prioritized too [51].

\section{LEM model for Cuban first level municipalities}

According to international experience some conditions are identified to successful LEM implementation in cuban municipalities [15]:

$\checkmark$ Recognition by all players of the local authorities leadership in local development and LEM

$\checkmark$ The municipal council have to accpet the resposibility for LEM integration in local development strategy

$\checkmark$ The availability of the needed information for LEM must be guaranteed by all players

A scheme of the scenario for LEM in Cuba is shown in figure 1. Since Cuban socio-economic system is founded on public property over main companies [18] and planning national economic. The scenario for municipal LEM is established by the yearly national economic plan (YNEP) which planning the energy available for all municipalities and companies of the country [44]. For YNEP the energy forecasted demand developed by the municipal government (MG) helped by LEM system are taken into account in order to national energy balance. In order to forecast energy demand the local stakeholder supply information to $\mathrm{MG}$ which according to local development strategy (LDS) and national policies developed the predicting.

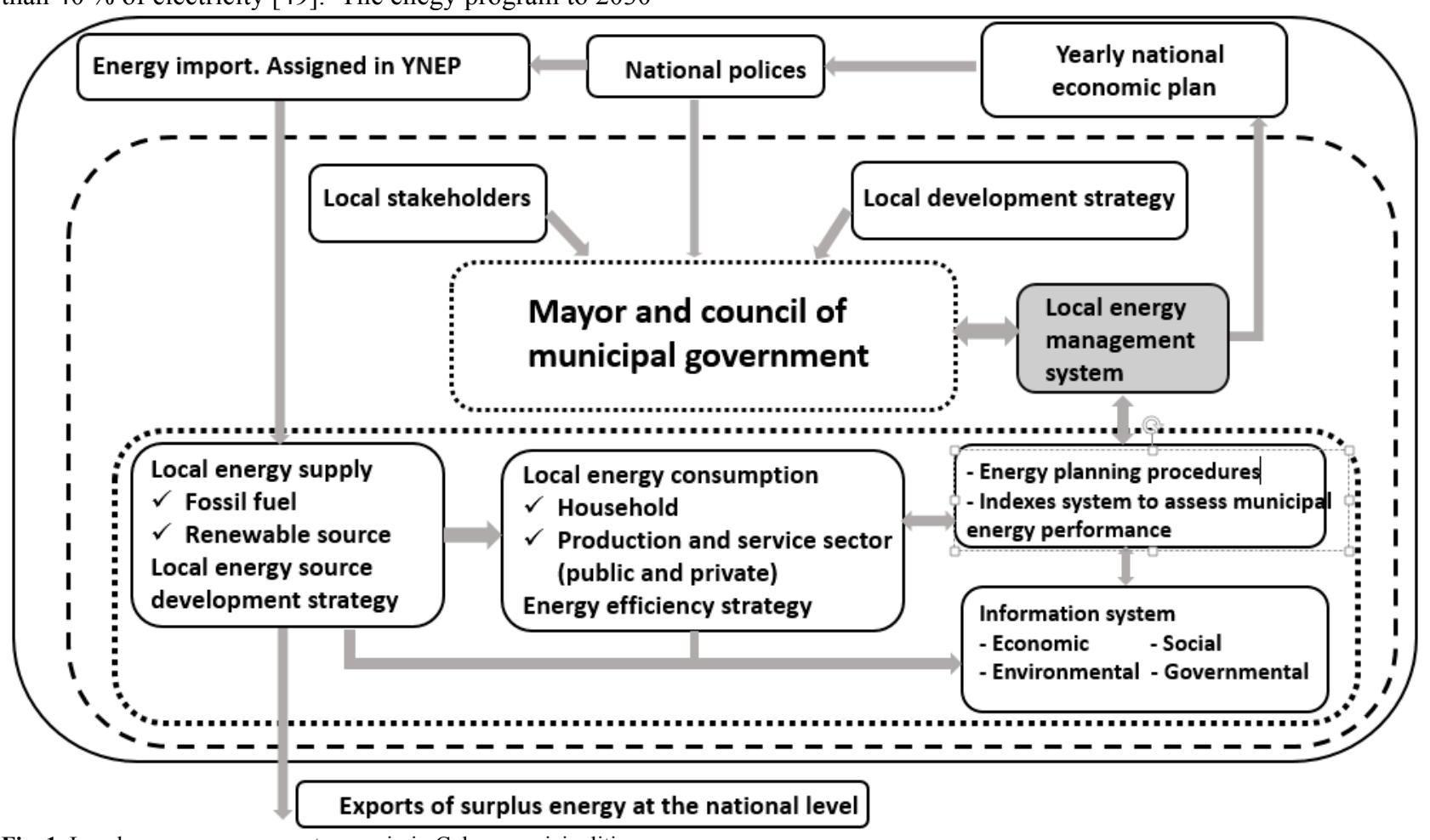

Fig. 1. Local energy management scenario in Cuban municipalities

The annual energy available in Cuban municipalities is the sum of energy assigned in the YNEP plus local energy sources and MG have to manage it to satisfy every necessity of LDE and citizens. If there is surplus energy must be 


\section{Oliveira/Journal of Engineering Science and Technology Review 11 (6) (2018) 1 - 6}

exported to the national level. LEM provides tools to MG for successful balance between available energy and consumed energy and assess the effectiveness of energy management also to forecast energy demand and local energy source development planning.

Local stakeholders are productive and services companies, the scientific community, opinion leaders and civil society organizations with roles and interests that can be framed in economic, political, cultural, educational, health, among others; which may be coincident or contradictory, but that can connect and produce common strategies [49,50]. LDS is defined by the council of municipal government in order to potentiate capacities for gradual and progressive implementation of the administrative, economic and financial decentralization as a principle of municipal organization and reorganization and continuous improvement of the citizen's quality of life [12].
Energy planning procedures and index systems to assess municipal energy performance are useful tools which allow the MG energy management to improve the energy consumption performance [15]. The Information system contributes to energy planning, management, and control [44] of LEM, with information gathering the local power generation including renewable, energy consumption in the municipality, and the variables that affect consumption locally. The indicators system for LEM are built through the processing of the influencing variables in energy consumption in order to drive the implementation and control of the LEM

LEM model is based on the continuous improvement cycle (PDCA) and must be integrated into the six functions of the municipals governance model developed by Boffill [44] as are shown in table 2.

Table 2. Relationship between model elements for energy management and functions for the process of governance in Cuban municipalities

\begin{tabular}{l|c|c}
\multicolumn{1}{c|}{ LEM model elements } & $\begin{array}{c}\text { Functions for the governance } \\
\text { process [44] }\end{array}$ & PDCA cycle \\
\hline Municipal energy diagnostic. & & \\
- Yearly energy plan balance & To diagnose & Plan. \\
- Energy importation & \\
- Local energy source contribution & \\
- Municipal Energy Efficiency plan production and services & \\
- Update ongoing investments in energy efficiency and renewable & \\
- Unergy & \\
\hline
\end{tabular}

Figure 2 showing a scheme of the LEM system. Since Cuba system is based in a planned economy the start point is the YNEP where energy and others resources availability are set for overall players in the national socioeconomic scenario and also a production and services to carry out is set too. In the municipal level, YNEP is coordinated with Local Development Strategy (LDS) and Municipal Goals which are the master lines of municipal government activities in order to citizens quality of life improved and were built with citizens and its leaders' participation.

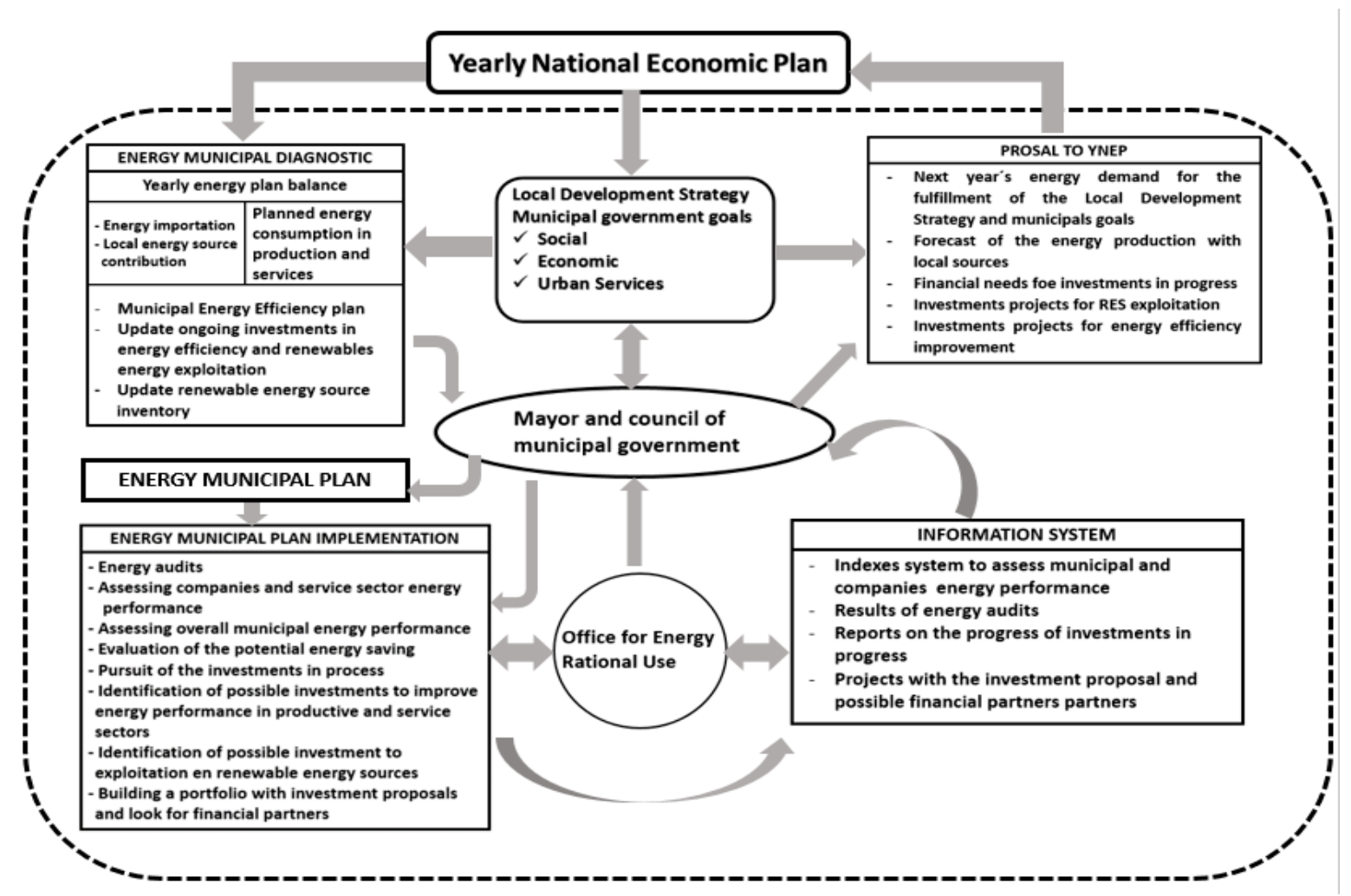

Fig. 2. Energy management model for local government bodies in Cuba 
The Municipal Energy Diagnostic is carried out by the Office of Energy Rational Use of (OERU) with the collaboration of experts from the main stakeholders. The annual energy balance checks if the energy carriers available for the municipality in the YNEP from local sources is sufficient to fulfill with the LDE and the municipal objectives. Also, plan for energy efficiency promotion are updated; the financial source assigned for investment in energy efficiency and renewable sources are checked too and the RES inventory is updated. Finally, a proposal for Energy Municipal Plan (EMP) is sent to Council of Municipal Government where corrections in LDE and municipal goals are introduced if is required by energy balance. The Municipal Council of Government approves the EMP and manages its implementation through the OERU. The Information System is able to control the EMP implementation and supply relevant data to MCG in order to systematically evaluate the behavior of the plan and take the necessary measures for its smooth running. The EMP performance is assessed at the end of the year and taking into account the municipal goals and LDE for next year, the municipal demand of energy carriers is proposed to including in YENP.

\section{Conclusion}

Paper shows that it is possible develop the LEM in a country, whose economy is not based on the market but on the planning and the collective property over the production companies and service facilities. In the specific conditions of Cuba are present the administrative, economic and social structures that will allow the successful establishment of the LEM with a significant contribution to local development.

The LEM model integrates the local government process model functions in Cuba (diagnose, evaluate, enrich, look out, optimize, and protect), and the elements of the LEM framed in the cycle of continuous improvement. 7.

This is an Open Access article distributed under the terms of the Creative Commons Attribution License

\section{References}

1. R,Guo, Y. Zhao, Y. Shi, F. Li, J.Hu and H. Yang, H, "Low carbon development and local sustainability from a carbon balance perspective", Resources, Conservation and Recycling, 2017, Vol 122, pp. 270-279.

2. C. Zou, Q. Zhao, G. Zhang and B. Xiong, (2016) "Energy revolution: From a fossil energy era to a new energy era" . Natural Gas Industry, 2016, Vol 3, No 1, pp 1-11.

3 L.Hens, J.Cabello, A. Sagastume, D. Garcia, J.Cogollos and C.Vandecasteele, "University-industry interaction on cleaner production. The case of the Cleaner Production Center at the University of Cienfuegos in Cuba, a country in transition”. Journal of Cleaner Production, 2017, Vol 142, pp 63-68.

4 K.Yigit and B. Acarkan, "A new electrical energy management approach for ships using mixed energy sources to ensure sustainable port cities", 2018, Sustainable cities and society, 2018 , Vol 40, pp 126-135.

5 International Energy Agency (IEA), 2008. "World Energy Outlook". IEA Books, Paris.

6 B.Morvaj, L. Lugaric, S. Krajcar. "Demonstrating smart buildings and smart grid features in a smart energy city". In Proceedings of 3rd International youth conference on energetics (IYCE); July 7-9, 2011, Leira, Portugal, p. 1-8

7 C. Calvillo, A. Sánchez and J. Villar, "Energy management and planning in smart cities", Renewable and Sustainable Energy Reviews, 2016, Vol 55, pp 273-287.

8 F. Sosa, (1981). "Ayuntamientos y ahorro energético". Revista de estudios de la vida local, 1981, Vol 210,pp 309-318.

9 C. Wene and B. Rydén, (1989). "A comprehensive energy model in the municipal energy planning process". Mathematical and Computer Modelling, 1989, Vol 12, No 8, pp 1050. doi:10.1016/0895-7177(89)90223-9

10 B. Koirala, E. Koliou, J. Friege, R. Hakvoort and P. Herder, "Energetic communities for community energy: A review of key issues and trends shaping integrated community energy systems". Renewable and Sustanaibility Energy Review, 2016, Vol 56, pp 722-744

11 Comisión Económica para América Latina y el Caribe CEPAL, "La hora de la igualdad”.. Publicación de Naciones Unidas LC/6.2603. 2014

12 J. Cabello, J. D, Covas, G. Hernandez, A. Sagastume, D. Garcia , C.Vandecasteele and L. Hens, (2014). "Comparative study of the urban quality of life in Cuban first-level cities from an objective dimension". Environment, Development and Sustainability, 2017,Vol 16, No 1, pp 195-215. doi:10.1007/s10668-013-9470-0

13 A. González, A. Arencibia and A. Saunders, "Red Nacional de Gestión del Conocimiento de la Energía: espacio colaborativo para la solución de problemas vinculados con la gestión de la información de la energía en Cuba". Ciencias de la Información, 2013, Vol 44, No 1, pp 11-28.

14 M. Rodríguez, "La ordenación y la planificación de las fuentes renovables de energía en la Isla de Cuba desde una perspectiva territorial. Estudio de caso en el municipio de Guamá a partir de un Geoportal", Tesis Doctoral. Departamento de Historia, Geografía y Filosofía. Universidad Pablo de Olavide. Sevilla. España. 2011

15 J. Correa, S. González, A. Hernández, 2017. "La gestión energética local: elemento del desarrollo sostenible en Cuba". Revista Universidad y Sociedad, 2017, Vol 9, No 2, pp 59-67.

16 F. Corsini, C. Certomà, M. Dyer and M. Frey,2018. "Participatory energy: Research, imaginaries and practices on people'contribute to energy systems in the smart city". Technological Forecasting and Social Change. In Press. https://doi.org/10.1016/j.techfore.2018.07.028

17 P. Striker, "Bringing social justice back in: Cuba revitalizes sustainable development”. Local Environment, 2010, Vol 15, No 2, pp 185-197.

18 J. Cabello, D. Garcia, A. Sagastume, R. Priego, L. Hens and C. Vandecasteele, "An approach to sustainable development: the case of Cuba". Environment, development and sustainability, 2012, Vol 14, No 4, pp 573-591.

19 Oficina Nacional de Estadística e Información (ONEI), “Anuario estadístico de Cuba". 2016. Avaliable from: http://www.one.cu/aec2015.htm. Last acssesed (15/05/2018)

20 M. Granberg, and L. Elander, (2007). "Local governance and climate change: reflections on the Swedish experience". Local environment, 2007, Vol 12, No 5, pp 537-548.

21 Z. Huang, H. Yu, Z. Peng and M. Zhao, (2015). "Methods and tools for community energy planning: A review". Renewable and Sustainable Energy Reviews, 2015, Vol 42, pp 1335-1348. doi:0.1016/j.rser.2014.11.042

22 M. Korai, R. Mahar and M. Uqaili, (2017). «The feasibility of municipal solid waste for energy generation and its existing management practices in Pakistan". Renewable and Sustainable Energy Reviews, 2017, Vol 72, pp 338-353.

23 A. Neves, V. Leal and J. Lourenço, "A methodology for sustainable and inclusive local energy planning", Sustainable cities and society, 2015, Vol 17, pp 110-121.

24 T. Bruckner, H. Groscurt and R. Kummel, "Competition and technologies synergy in municipal between energy systems". 1997, Energy, Vol 22, No 10, pp 1005-1014.

25 F. Butera,"Moving towards municipal energy planning - the case of Palermo: the importance of non-technical issues" . Renewable Energy, 1998, Vol 15, pp 349-355 
26 N. Wohlgemuth, "Cost benefit indicators associated with the integration of alternative energy sources: a systems approach for Carinthia, Austria", 1999, Renewable Energy, 1999, Vol 16, pp 1147-1150 . doi:PII: S09060-148(98)00446-7.

27 G. Sundberg and B. Karlsson, "Interaction effects in optimizing a municipal energy system". Energy, 2000, Vol 25, pp 877-891. doi:10.1016/S0360-5442(00)00022-0.

28 B. Rolfsman,”Optimal supply and demand investments in municipal energy systems". Energy Conversion and Managemen, 2004, Vol 45, pp 595-611. doi:0.1016/S01968904(03)00174-2

$29 \mathrm{P}$. Fleming and P. Webber, "Local and regional greenhouse gas management", Energy Policy, 2004, Vol 32, No 8, pp 761-771. doi:10.1016/S0301-4215(02)00339-7

30 J. García, (2006). "Eficiencia energética a nivel local: Los planes de Optimización Energética Municipal (POES) en la provincia de Jaén". SUMUNTÁN, 2007, Vol 23, pp 153-184.

31 H. Zia, H and V.Deyadas, "Energy management in Lucknow city", Energy Policy, 2007, Vol 35, No 10, pp 4847-4868. doi:10.1016/j.enpol.2007.04.018

32 J. Inver (2009), "Municipal Energy Planning - Scope and Method Developmen"t. Linköping University, Department of Management and Engineering, Division for Environmental Technology and Management, Linköping Studies in Science and Technology. Linköping, Sweden: Printed by LiU-tryck. Obtenido de http://www.iei.liu.se/envtech

33 D. Genevieve, "Community energy planning in Canada: The role of renewable energy" Renewable and Sustainable Energy Reviews, 2009, Vol. 13, N N $^{\circ}$ 1, p. 2088-2095.

34 Boletín Oficial de la Comunidad de Madrid III (BOCM), Boletín Oficial de la Comunidad de Madrid III. "Administración local.Administración local. Madrid: Ayuntamiento de RivasVaciamadrid". 2010

35 Q. Lin and G. Huang, (20110),"An inexact two-stage stochastic energy systems planning model for managing". Energy, 2010, Vol 35, pp 2270-2280. doi:10.1016/j.energy.2010.01.042

36 K. Sperling, E. Hvelplund and B. Vad Mathiesen, "Centralisation and decentralisation in strategic municipal energy planning". Energy Policy, 2011, Vol 39, pp 1338-1351. doi:10.1016/j.enpol.2010.12.006

37 Y. Zhu, G. Huang, Y. Li, L. He and X. Zhang, "An interval fullinfinite mixed-integer programming method for planning". Applied Energy, 2011, Vol 88, No 8, pp 323-337, doi::10.1016/j.apenergy.2011.01.058

38 C. Brandoni and F Polonara, (2012). "The role of municipal energy planning in the regional energy-planning process". Energy, 2012, Vol 48, pp 323-338. doi:10.1016/j.energy.2012.06.061

39 Z. Huang, H. Yu, Z. Peng and M. Zhao, (2015). "Methods and tools for community energy planning: A review". Renewable and
Sustainable Energy Reviews, 2015, Vol 42, pp 1335-1348. doi:0.1016/j.rser.2014.11.042

40 P. Fenton, S. Gustafsson, J. Ivner and J.Palm, "Sustainable Energy and Climate Strategies: lessons from planning". Journal of Cleaner Production, 2016, Vol 98, pp 213-221. doi:http://dx.doi.org/10.1016/j.jclepro.2014.08.001

41 J. Nilsson and A. Ma rtensson, "Municipal energy-planning and development of local energy-systems", Applied Energy , 2003, Vol 73, pp 179-187. doi:10.1016/S0306-2619(03)00062-X

42 J. Ivner, A. Bjorklund, K. Dreborg, J. Johansson, P. Viklund and H. Wiklund, (2010). "New tools in local energy planning. experimenting with scenarios, public participation and environmental assessment". Local Environment: The International Journal of Justice and Sustainability, 2010, Vol 5, No 2, pp 105 120. doi:10.1080/13549830903527639

43 Oficina nacional de Estadistica e Informacion (ONEI),. (2016). "Anuario Estadistico de Cuba, 2015", Avaliable from: http://www.one.cu/aec2015.htm, Last acssesed (15/05/2018)

44 S. Boffill, C. Calcines and S. Sanchez, "Modelo de gestión para contribuir al desarrollo local, basado en el conocimiento y la innovación en Cuba" . Ingeniería Industrial, 2010, Vol 30, No 2, pp $52-29$

45 J. Suarez, P. Beaton, R. Faxas and C. Luengo, "The state and prospects of renewable energy in Cuba". Energy Sources Part B Econ. Plan. Policy, 2016, Vol 11, pp 111-117.

46 C. Benzing, C., 2005. Cuba in the "Special period" really over? Int Adv. Econ. Res., 2005, Vol 11, pp 69-82.

47 T. Fletcher, "La Revolución Energética: A Model for Reducing Cuba's Dependence", 2017, International Journal of Cuban Studies, 2017, Vol. 9, No. 1, pp. 91-116

48 M. Panfil, D. Whittle and K. Silverman (2017). "What's next for Cuba's electricity sector?". The Electricity Journal, 2017, Vol 30, No 8, pp 38-44.

49 J. Núñez, L. Montalvo, I. Pérez, "Universidad, conocimiento y desarrollo local (basado en el conocimiento)" en Ada Guzón (ed.), Desarrollo local en Cuba. Retos y perspectivas, Editorial Academia, La Habana, pp. 205-219, 2006

50 J. Núñez, A. Alcázar and T. Proenza, "Una década de la Red Universitaria de Gestión del Conocimiento y la Innovación para el Desarrollo Local en Cuba. Retos de la Dirección, 2017, Vol 11, No 2, pp 228-244.

51 J. Cabello, A., Sagastume, D. Garcia, J, Martínez, L. Hens, C. Vandecasteele, "Bridging universities and industry through cleaner production activities. Experiences from the Cleaner Production Center at the University of Cienfuegos, Cuba". Journal of cleaner production, 2015, Vol 108, pp 873-882. 